Universidad de Lima

Facultad de Derecho

Carrera de Derecho

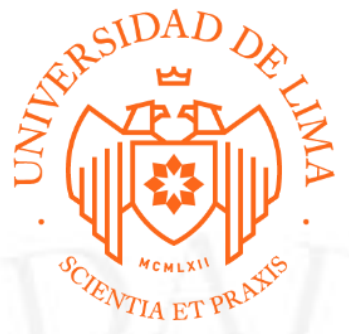

\title{
ARBITRAJE: "IMPUGNACIÓN DE ACUERDO SOCIETARIO" Y CONSTITUCIONAL: "ACCIÓN DE
} AMPARO"

Trabajo de suficiencia profesional para optar el Título Profesional de Abogado

\author{
Jaime Diego Sivirichi Flores
}

Código 20092596

$$
\text { Lima - Perú }
$$

Agosto de 2019 


\section{INFORME DE EXPEDIENTE ARBITRAL}

\section{RESUMEN}

El presente informe analiza la demanda de impugnación de acuerdo societario interpuesta por Y. O. L. A. contra la Empresa AAA S.A.A., con la finalidad de ejercer los derechos que la asisten como socia de la referida empresa, como consecuencia de la elección del Directorio en la Junta General de Accionistas celebrada el 30 de abril de 2009, en contravención del estatuto y la Ley General de Sociedades. En ese sentido se analiza el expediente tramitado en sede arbitral, verificando si las condiciones exigidas para la toma de acuerdos en la Junta General de Accionistas son respetadas, así como el curso arbitral de la demanda.

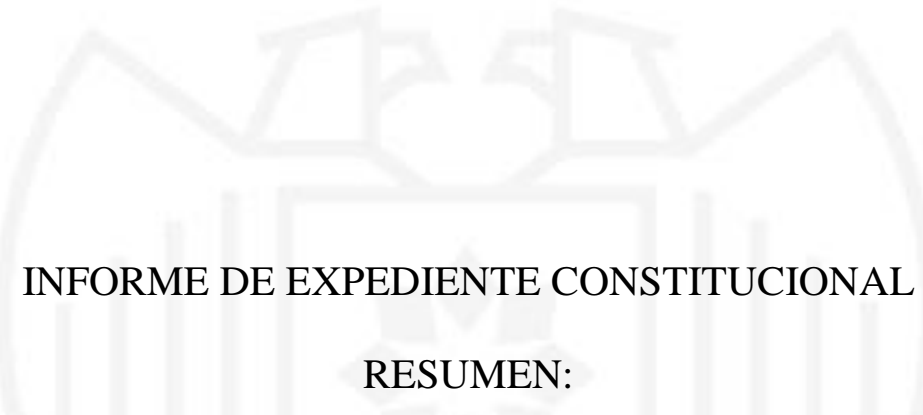

El presente informe analiza la demanda de amparo interpuesta por CL S.A. contra El Ministerio de Economía y Finanzas, con la finalidad de que se declare inaplicable el decreto supremo $\mathrm{N}^{\circ}$ 158-2007-EF, que dispone la reducción de $12 \%$ a $0 \%$ de los derechos arancelarios de importación ad valorem CIF a las sub partidas nacionales correspondientes al cemento 2523100000 (cementos sin pulverizar "Clinker") y 2523 290000 (otros). En ese sentido, se analiza si la modificación de derechos arancelarios ad valorem $\mathrm{CIF}$ que no sea de manera gradual suponen una afectación a la seguridad jurídica, proporcionalidad, no discriminación, igualdad de los competidores ante la ley y gradualidad,

De esta manera se exponen los diversos actos procesales y sentencias, a fin de que resulte comprensible la forma en la cual se ha tramitado el proceso. Además, contiene el análisis doctrinario y jurisprudencial sobre la materia de acción de amparo y finalmente; describe las conclusiones arribadas a lo resuelto y la opinión jurídica del caso. 